Вестник ВГУ. Серия: Право

УДК 342.922

DOI https://doi.org/10.17308/vsu.proc.law.2020.3/2983

\title{
РАЗГРАНИЧЕНИЕ АДМИНИСТРАТИВНО-ПРАВОВОГО И КОНСТИТУЦИОННО-ПРАВОВОГО СТАТУСОВ УПОЛНОМОЧЕННОГО ПО ПРАВАМ ЧЕЛОВЕКА В СУБЪЕКТЕ РОССИЙСКОЙ ФЕДЕРАЦИИ
}

\author{
Т. В. Колобова
}

Воронежский государственный университет

Поступила в редакцию 20 мая 2020 г.

\begin{abstract}
Аннотации: автор обосновывает наличие у регионального омбудсмена, помимо конституционно-правового, также адлинистративно-правового статуса, реализуелого в адлинистративных отношениях с гражданали и исполнительньлии органали государственной власти.

Ключевые слова: уполнолоченный по правам человека, олбудсмен, субъект Российской Федераиии, адлинистративно-правовой статус, конституиионно-правовой статус.
\end{abstract}

\begin{abstract}
: the author justifies the regional ombudsmen's availability of constitutional legal status and administrative legal status. The latter is implemented in administrative relations with citizens and executive state departments.

Key words: the Commissioner for human rights, ombudsmen, subject of the Russian Federation, administrative legal status, constitutional legal status.
\end{abstract}

Принятие Федерального закона от 18 марта 2020 г. № 48-ФЗ «Об уполномоченных по правам человека в субъектах Российской Федерации» ${ }^{1}$ ознаменовало собой новый этап в развитии данного института. Была подчеркнута актуальность правозащитной и контрольной деятельности региональных уполномоченных (далее - омбудсменов) ${ }^{2}$ и важность регулирования на федеральном уровне общественных отношений, в которых они участвуют. Вышеуказанный закон устанавливает единые основы статуса региональных омбудсменов в Российской Федерации, закрепляет новые контрольные полномочия и гарантии деятельности. В связи с этим для юридической науки актуальным является анализ обновленно-

184 го правового статуса уполномоченных по правам человека в субъектах Федерации с учетом новелл, привнесенных Федеральным законом от 18 марта 2020 г. № 48-Ф3.

Термин «статус» имеет латинские корни и обозначает состояние, положение ${ }^{3}$. При исследовании понятия «правовой статус» Д. Н. Бахрах об-

\footnotetext{
${ }^{1}$ Рос. газета. 2020. 20 марта.

2 Данный институт впервые появился в Швеции в XIX в. под названием «ombudsman», что означает «представитель интересов» (см.: Бойщова В. В. Служба защиты прав человека и гражданина. Мировой опыт. М., 1996. С. 6).

${ }^{3}$ См.: Ожегов С. И. Словарь русского языка / под ред. Н. Ю. Шведовой. М., 1991. C. 762.

(C) Колобова Т. В., 2020
} 
ращает внимание на то, что это - комплексное образование, состоящее из норм различных отраслей права ${ }^{4}$.

В наиболее общем виде правовой статус субъекта означает юридическое закрепление его положения в обществе. По мнению Б. В. Россинского и Ю. Н. Старилова, правовой статус (правовое положение) государственного служащего - это совокупность прав, свобод, обязанностей, ограничений, запретов, ответственность служащих, установленных законодательством и гарантированных государством ${ }^{5}$.

Под правовым статусом регионального омбудсмена в юридической науке понимается предусмотренная нормами законодательства совокупность государственно-правовых установлений, определяющих права, обязанности, требования, ответственность омбудсмена, условия его деятельности и функционально-целевую установку ${ }^{6}$. В правовой статус уполномоченного включаются также вопросы, связанные с назначением лица на эту должность и освобождением от нее, взаимодействием с другими органами государственной власти и международными институтами правовой защиты прав человека, функционированием аппарата омбудсмена и др.

Традиционно правовой статус уполномоченного по правам человека был предметом исследований науки конституционного права как правовое положение государственного правозащитного органа. При этом точка зрения об омбудсмене как административно-правовом институте также имела место, например в работах административиста А. Б. Зеленцова ${ }^{7}$

В последнее время в юридической науке все чаще появляются публикации об административно-правовой основе статуса уполномоченного по правам человека, наличие которой обосновывается местом омбудсменов и их аппаратов в структуре государственного механизма ${ }^{8}$, наличием «мягких властных распорядительных» полномочий ${ }^{9}$ в отношении испол-

${ }^{4}$ См.: Бахрах Д. Н., Россинский Б. В., Старилов Ю. Н. Административное право : учеб. для вузов. 3-е изд., пересмотр. и доп. М., 2008. С. 294.

${ }^{5}$ Общее административное право : учебник : в 3 т. Т. 1 / под ред. Ю. Н. Старилова. 2-е изд., пересмотр. и доп. Воронеж, 2016. С. 399.

${ }^{6}$ См.: Лукашова Н. Ф. Взаимодействие уполномоченного по правам человека в субъекте Федерации с органами государственной власти и другими структурами в сфере защиты прав и свобод человека и гражданина : конституционно-правовой аспект : дис. ... канд. юрид. наук. Саратов, 2010. С. 42-43.

${ }^{7}$ См.: Зеленцов А. Б. Административная юстиция. Общая часть. Теория судебного административного права : учеб. пособие для студентов вузов, обучающихся по специальности «юриспруденция». М., 2017. С. 95.

${ }^{8}$ См.: Москалькова T. Н. Институт уполномоченных по правам человека в государственном механизме России // Административное право и процесс. 2018. № 12 . С. 52-59.

${ }^{9}$ См.: Плуталов И. Ю. Административно-правовая основа статуса уполномоченного по правам человека в Российской Федерации // Административное право и процесс. 2019. № 10. С. 74. 


\section{Вестник ВГУ. Серия: Право}

нительных органов государственной власти и специальной процедуры рассмотрения уполномоченными по правам человека жалоб граждан ${ }^{10}$.

По нашему мнению, российские омбудсмены обладают комплексным статусом, регулируемым нормами различных отраслей права. Федеральный закон от 18 марта 2020 г. № 48-ФЗ «Об уполномоченных по правам человека в субъектах Российской Федерации» не привнес ничего существенно нового в конституционно-правовой статус региональных омбудсменов, но существенно расширил административно-правовой статус. Разграничим их следующим образом.

Содержанием конституционно-правового статуса уполномоченного по правам человека в субъекте Федерации является совокупность законодательных установлений, регулирующих целевую установку омбудсмена (цели и общие задачи деятельности); организационно-правовую основу (требования к кандидату на должность, порядок назначения и освобождения от должности, запреты и ограничения); полномочия в сферах деятельности, не связанных с государственным контролем (правовое просвещение, развитие сотрудничества в области прав человека и др.).

Административно-правовой статус субъекта, в свою очередь, реализуется в административно-правовых властных отношениях в сфере государственного управления. Нормы административного права присутствуют также в Федеральном законе «Об уполномоченных по правам человека в субъектах Российской Федерации как регулятор отношений омбудсменов:

- с гражданами при рассмотрении их обращений;

- с исполнительными органами государственной власти, органами местного самоуправления и должностными лицами, являющимися объектом контрольной деятельности уполномоченных по правам человека.

В содержание административно-правового статуса омбудсменов входят задачи по совершенствованию практики деятельности исполнительных органов публичной власти; компетенция (полномочия) по разрешению административно-правовых споров граждан с органами государственной власти и местного самоуправления; административная ответственность за вмешательство в деятельность омбудсмена как гарантия его деятельности.

186 Добавим также, что точка зрения о наличии у уполномоченных по правам ребенка административно-правового статуса является общепризнанной ${ }^{11}$. Согласно Федеральному закону от 27 декабря 2018 г. № 501Ф3 «Об уполномоченных по правам ребенка в Российской Федерации» ${ }^{12}$ уполномоченные входят в систему органов исполнительной власти, назначаются Президентом (федеральный Уполномоченный) или высшим должностным лицом субъекта Федерации (региональные уполномоченные). Отметим, что основная разница между российскими уполномо-

${ }^{10}$ См.: Плуталов И. Ю. Указ. соч. С. 73.

${ }^{11}$ См.: Шамрин М. Ю. Административно-правовой статус уполномоченного по правам ребенка : дис. ... канд. юрид. наук. М., 2014. С. 56.

${ }^{12}$ Собр. законодательства Рос. Федерации. 2018. № 53 (ч. 1). Ст. 8427. 
ченными обшей компетенции и специализированными - в положении в структуре государственного аппарата и объектах контрольной деятельности; их функции и полномочия, в том числе контрольные, существенно не отличаются.

Рассмотрим административно-правовой статус региональных омбудсменов подробнее.

1. В законах некоторых субъектов Федерации закреплены также задачи деятельности уполномоченных, дополняющие положения Федерального закона «Об уполномоченных по правам человека в субъектах Российской Федерации» ${ }^{13}$. Например, задача по взаимодействию с государственными органами субъекта Федеращии в целях защиты прав и свобод граждан (например, п. «б» ч. 2 ст. 3 Закона Брянской области от 8 декабря 2004 г. № 80-з «Об уполномоченном по правам человека в Брянской области») ${ }^{14}$.

В ст. 5 Закона Тверской области от 6 июня 2012 г. № 36-3О «Об уполномоченном по правам человека в Тверской области и уполномоченном по правам ребенка в Тверской области» закреплены задачи омбудсменов по содействию органам государственной власти области и органам местного самоуправления в создании системы защиты прав, свобод и законных интересов человека и гражданина, прав, свобод и законных интересов ребенка, а также по содействию органам государственной власти в создании условий для развития институтов гражданского общества.

В Законе Владимирской области от 9 июля 2013 г. № 70-ОЗ «Об уполномоченном по правам человека во Владимирской области» и Законе Ивановской области от 8 декабря 2010 г. № 140-О3 «Об уполномоченном по правам человека в Ивановской области» ${ }^{15}$ закреплена задача уполномоченного по содействию в координации деятельности органов государственной власти и органов местного самоуправления в области защиты прав и свобод человека и гражданина.

Отметим, что наделение омбудсменов функцией координации предусмотрено также ч. 2 ст. 12 Федерального закона от 18 марта 2020 г. № 48-ФЗ: речь идет о координации деятельности специализированных уполномоченных (по правам ребенка, по правам коренных малочисленных народов) и других должностных лиц, уполномоченных осуществлять 187 зашиту прав иных категорий граждан в субъекте РФ.

2. Компетенция уполномоченного по правам человека - основной элемент административно-правового статуса омбудсмена. Это нормативно

${ }^{13}$ Федеральный закон от 18 марта 2020 г. № 48-ФЗ в ч. 4 ст. 1 перечисляет общие задачи омбудсменов, определяющие их основные направления деятельности: восстановление прав и свобод человека и гражданина; совершенствование законодательства, правовое просвещение и развитие международного сотрудничества в области прав человека.

${ }^{14}$ Официальный интернет-портал правовой информации. URL: http://www. pravo.gov.ru

15 Там же. 


\section{Вестник ВГУ. Серия: Право}

закрепленная система полномочий (прав и обязанностей) в установленной сфере деятельности - контрольной, правотворческой, координирующей, аналитической и др., которыми уполномоченный наделяется государством для решения вопросов обеспечения защиты и соблюдения прав и свобод человека и гражданина в деятельности исполнительных органов государственной власти, местного самоуправления, их должностных лиц.

Компетенция региональных омбудсменов по разрешению административно-правовых споров граждан с органами публичной власти уточнена и расширена Федеральным законом от 18 марта 2020 г. № 48-ФЗ по сравнению с Федеральным законом «Об общих принципах организации законодательных (представительных) и исполнительных органов государственной власти субъектов Российской Федерации» ${ }^{16}$. Она распространяется на решения или действия (бездействие) всех территориальных органов федеральных органов исполнительной власти, действующих на территории субъекта $Р \Phi^{17}$, органов государственной власти или иных государственных органов субъекта РФ (кроме законодательных (представительных) органов государственной власти субъектов РФ), органов местного самоуправления, иных муниципальных органов, организаций, действующих на территории субъекта РФ, наделенных отдельными государственными или иными публичными полномочиями.

Федеральный закон «Об уполномоченных по правам человека в субъектах Российской Федерации» закрепляет адлинистративную процедуpy рассмотрения омбудсменами жалоб и иных обращений граждан с четким установлением сроков каждой стадии: приема жалобы, проведения проверки, принятия решения по итогам рассмотрения жалобы (ст. 9-11). Процедура включает в себя обязательное условие подачи жалобы - обжалование заявителем решений или действий (бездействия), по его мнению, нарушивших (нарушающих) его права и свободы, в судебном либо административном порядке, а также пресекательный срок для подачи жалобы - один год. Анализируя аналогичные нормы в Федеральном конституционном законе от 26 февраля 1997 г. № 1-ФКЗ «Об уполномоченном по правам человека в Российской Федерации» ${ }^{18}$, И. Ю. Плуталов подчеркивает, что это отношения юридически неравноправных сторон, носящие односторонний властный характер со стороны уполномоченного, что свидетельствует об административной природе норм, регулирующих такие отношения ${ }^{19}$.

${ }^{16}$ Об общих принципах организации законодательных (представительных) и исполнительных органов государственной власти субъектов Российской Федерации : федер. закон от 6 октября 1999 г. № 184-ФЗ // Рос. газета. 1999. 19 окт.

17 Согласно Федеральному закону «Об общих принципах организации законодательных (представительных) и исполнительных органов государственной власти субъектов Российской Федерации» уполномоченные рассматривают жалобы только на те территориальные органы федеральных органов исполнительной власти, руководство деятельностью которых осуществляет Правительство РФ.

${ }_{18}$ Рос. газета. 1997. 4 марта.

${ }^{19}$ См.: Плуталов И. Ю. Указ. соч. С. 72. 


\section{Административное право и процесс}

Федеральный закон от 18 марта 2020 г. № 48-Ф3 разделяет полномочия омбудсменов на две группы: полномочия при рассмотрении жалобы и по итогам рассмотрения в случае выявления нарушений. Если исходить из позиции, что властные полномочия предполагают пересмотр решений, принятых другими органами и должностными лицами, то констатируем, что уполномоченный по правам человека такими полномочиями не обладает. Однако у омбудсмена все же имеются инструменты повелительно-управляющего воздействия, перечень которых был расширен Федеральным законом от 18 марта 2020 г. № 48-ФЗ. Это свидетельствует об определенном объеме взаимоотношений властного характера между уполномоченным и органами публичной власти, должностными лицами, а также гражданами ${ }^{20}$.

Так, дополнены полномочия омбудсменов при проверке обстоятельств по жалобе, в частности они наделяются правом при рассмотрении жалобы обращаться в суд с ходатайством об ознакомлении с материалами по гражданскому или административному делу, решение по которому вступило в законную силу.

Региональный омбудсмен наделяется важным полномочием проведения проверки обстоятельств по собственной инициативе и принятия соответствующих мер в пределах своей компетенции в ряде случаев: при наличии информации о массовых или грубых нарушениях прав и свобод человека и гражданина; в случаях, имеющих особое общественное значение; в случаях, связанных с необходимостью защиты интересов лиц, не способных самостоятельно использовать правовые средства защиты.

В случае, если по итогам проверки уполномоченный по правам человека придет к выводу о нарушении прав или свобод заявителя, в его распоряжении имеются законодательно установленные правовые, в том числе административно-правовые, механизмы защиты прав и свобод человека и гражданина, под которыми в юридической литературе понимаются закрепленные в законодательстве средства и способы, направленные на содействие в соблюдении и защите прав и свобод человека и гражданина ${ }^{21}$.

Согласно ст. 11 Федерального закона «Об уполномоченных по правам человека в субъектах Российской Федерации» по итогам рассмотрения жалобы омбудсмен вправе обратиться в суд с административным исковым заявлением (иском) в защиту прав и свобод человека и гражданина (в том числе неограниченного круга лиц), нарушенных решениями или действиями (бездействием) государственного органа, муниципального органа, организации, должностного лица, государственного или муниципального служащего, а также лично или через своего представителя участвовать в процессе по делу о защите прав и свобод человека и гражданина в соответствии с законодательством Российской Федерации.

${ }^{20}$ См.: Москалькова Т. Н. Указ. соч. С. 56.

${ }^{21}$ См.: Шамрин М. Ю., Мигачева Е. В. Административно-правовые механизмы защиты прав человека в зарубежных государствах // Административное право и процесс. 2017. № 9. С. 52. 


\section{Вестник ВГУ. Серия: Право}

Соответствующее право уполномоченного по правам человека в субъекте РФ закреплено в ч. 4 ст. 218 Кодекса административного судопроизводства Российской Федерации ${ }^{22}$.

Отметим также, что Федеральный закон от 18 марта 2020 г. № 48-ФЗ не использует уже устоявшийся в федеральном и региональном законодательстве термин «заключение уполномоченного по правам человека». Он закрепляет полномочие омбудсменов направить государственному органу, муниципальному органу, организации, должностному лицу, в решениях или действиях (бездействии) которых он усматривает нарушение прав и свобод человека и гражданина, свои реколендации относительно возможных и необходимых мер по восстановлению указанных прав и свобод. Установлена обязанность государственного органа, муниципального органа, организации, должностного лица, получивших рекомендации уполномоченного, в течение 30 дней рассмотреть их и о принятых мерах в письменной форме сообщить уполномоченному по правам человека в субъекте РФ.

Таким образом, наличие административно-правового статуса у уполномоченного по правам человека в субъектах РФ обусловлено тем, что омбудсмен является лицом, замещающим государственную должность, наделенным фбункиияли контроля и координации исполнительных органов государственной власти и специализированных омбудсменов, а также полнолочияли по разрешению адлинистративно-правовых споров граждан с исполнительными органами государственной власти, органами местного самоуправления и должностными лицами.

По нашему мнению, одним из важнейших направлений усиления административно-правового статуса регионального уполномоченного по правам человека является наделение их полномочием выносить обяза-

œ тельные для органов публичной власти решения в случае установления

이 форакта нарушения прав граждан, т. е. придать их заключениям юридическую силу. Как отмечал С. А. Авакьян применительно к деятельности уполномоченного по правам человека, «в силу ментальности населения институт общества, созданный законодательной властью и пытающийся влиять на деятельность исполнительной власти посредством пожеланий

190 и рекомендаций, является нежизненным. Не приживаются на российской почве органы, не имеющие властных полномочий» ${ }^{23}$.

Предлагается абз. 2 ч. 1 ст. 11 Федерального закона «Об уполномоченных по правам человека в субъектах Российской Федерации» изложить в следующей редакции: «...направить в территориальный орган федерального органа исполнительной власти, орган государственной власти или иной государственный орган субъекта Российской Федерации, орган местного самоуправления, иной муниципальный орган, организацию,

${ }^{22}$ Кодекс административного судопроизводства Российской Федерации : феедер. закон от 8 марта 2015 г. № 21-ФЗ // Рос. газета. 2015. 11 марта.

${ }^{23}$ Авакьян С. А. Пробелы и дефекты в конституционном праве и пути их устранения // Конституционное и муниципальное право. 2007. № 8. С. 6. 


\section{Административное право и процесс}

действующую на территории субъекта Российской Федерации, наделенную отдельными государственными или иными публичными полномочиями, или должностному лицу, в решениях или действиях (бездействии) которого он усматривает нарушение прав и свобод человека и гражданина, свое заключение, содержащее указания относительно необходимых мер по восстановлению указанных прав и свобод. Государственные органы, муниципальные органы, организации, должностные лица, получившие заключение уполномоченного по правам человека в субъекте Российской Федерации, обязаны в течение 30 дней рассмотреть его, принять меры и в письменной форме сообщить о результатах уполномоченному по правам человека в субъекте Российской Федерации;».

Воронежский государственный университет

Колобова Т. В., советник аппарата уполнолоченного по правал человека в Воронежской области

E-mail: kolobova21@yandex.ru
Voronezh State University

Kolobova T. V., Advisor of Office of the Commissioner for Human Rights in Voronezh Region

E-mail: kolobova21@yandex.ru 